\title{
Comparison of the Level of Boron Concentrations in Black Teas with Fruit Teas Available on the Polish Market
}

\author{
Anetta Zioła-Frankowska, ${ }^{1}$ Marcin Frankowski, ${ }^{1}$ Karel Novotny, ${ }^{2}$ and Viktor Kanicky ${ }^{2}$ \\ ${ }^{1}$ Department of Water and Soil Analysis, Faculty of Chemistry, Adam Mickiewicz University in Poznań, Umultowska 89b, \\ 61-614 Poznań, Poland \\ ${ }^{2}$ Department of Chemistry, Faculty of Science, Masaryk University, 61137 Brno, Czech Republic
}

Correspondence should be addressed to Anetta Zioła-Frankowska; anettazf@amu.edu.pl

Received 10 June 2014; Revised 11 August 2014; Accepted 14 August 2014; Published 14 October 2014

Academic Editor: M. Carmen Yebra-Biurrun

Copyright (C) 2014 Anetta Zioła-Frankowska et al. This is an open access article distributed under the Creative Commons Attribution License, which permits unrestricted use, distribution, and reproduction in any medium, provided the original work is properly cited.

\begin{abstract}
The determination of boron by inductively coupled plasma-atomic emission spectrometry has been carried in water-soluble and acid soluble (total content) fractions of 36 samples of traditional black tea and fruit brew. The estimation of the impact of the type of tea on the concentration of boron in water-soluble and acid extracts and potential human health risk from the daily intake of boron was carried out in this study. The levels of boron differed significantly in black and fruit tea types. The mean total content of boron ranged from 8.31 to $18.40 \mathrm{mg} / \mathrm{kg}$ in black teas, from 12.85 to $15.13 \mathrm{mg} / \mathrm{kg}$ in black tea with fruit flavor, and from 12.09 to $22.77 \mathrm{mg} / \mathrm{kg}$ in fruit brews. The degree of extraction of boron in black tea ranged from $8 \%$ to $27 \%$ and for fruit tea from $17 \%$ to $69 \%$. In addition, the values below $25 \%$ were of black teas with fruit flavors. The daily intake of B from tea infusions (three cups/day) is still within the average daily intake except for some of the fruit brews which exceed acceptable regulations of the daily intake of total boron by humans. Hence, it may not produce any health risks for human consumption, if other sources of metal contaminated food are not taken at the same time.
\end{abstract}

\section{Introduction}

Boron is an essential element affecting the growth and development of plants $[1,2]$. In the form of boric acid or borates it is necessary for the growth of land plants, especially vascular plants, and thus indirectly essential for the continuation of animal life. However, in large amounts the above compounds are toxic to organisms in general, including plants [3]. The toxicity symptoms of boron can vary from the necrosis of some plant organs to the death of the whole plant depending on the extent and severity of toxicity [4].

The fundamental importance of boron to animals and humans has not been identified precisely, although some evidence strongly indicates that boron is probably an essential micronutrient $[2,4,5]$. The presence of boron has been demonstrated to favorably affect the function and composition of several body compartments, such as the brain, the skeleton, and also the immune system in humans $[2,6]$.
Too high concentration of boron in human body may result in nausea, vomiting, diarrhea, and lethargy. The Word Health Organization has announced that a safe range of boron intake for adults is $1-13 \mathrm{mg} / \mathrm{day}[6]$.

It should be underlined that the existing evidence from plant, bacteria, animal, and human experiments shows that boron is a dynamic trace element affecting an exceptionally large number of seemingly unrelated biological functions [7]. That is why the control of boron levels in biological samples, especially those related to human nutrition, is needed [8]. It has been stated that food is a primary source of boron that is ingested by humans. Starting in the 1870 s, for about 50 years, the addition of borates was one of the best methods of preserving food products. The research by Wiley [9], which presented the evidence of the negative effects of boric acid consumption in doses greater than $0.5 \mathrm{~g}$ per day for 50 days, contributed to the fact that borates and boric acid were essentially forbidden as food preservatives throughout 
the world [5]. Taking into account that excess of boron is toxic to human health, its analysis in food is becoming increasingly important [8].

The most popular nonalcoholic beverage consumed by about half of the world's population is tea (Camellia sinensis L.) prepared from steamed and dried leaves [10]. Tea can be classified into six basic categories: white, green, yellow, oolong, black, and pu-erh [11, 12]. Moreover, the types of tea are distinguished on the basis of the degree of fermentation, on which the final composition of tea, including its aroma, colour, and taste, is also dependent [13]. It is well known that tea contains many different compounds, including minerals and trace elements. The elements included in a brew of tea are differentially extracted into infusions, so the prepared beverage can be a reliable dietary source of essential major, minor, and trace elements, including boron $[12,14]$.

Currently used methods of boron determinations are spectrophotometric methods based on the creation of colored complex of boron with a suitable reagent, which have low precision and numerous interferences [15]. In the case of atomic absorption methods, despite the better sensitivity and lower detection limits they are burdened with interference and memory effect and the loss of boron in the case of not applying the appropriate modifier (GF-AAS). However, the use of ICP-AES methods provides higher sensitivity, lower detection limits, and less chemical interferences and is less time consuming $[16,17]$. The ICP-AES method was used for the determination of boron in many food products, for example, in honey [18], peanut kernels [19], nuts and seeds [20], onions [21], herb samples [22], and liquid nutritional foods [23].

The aims of this study were to determine the total content of boron in samples of teas available on the Polish market, to mark the concentration of boron in the water-soluble fraction of tea samples, to establish the impact of tea type on the boron concentration in water and acid extracts and to estimate the daily intake of boron on the basis of boron in a cup of tea, and to determine the potential human health risk.

\section{Material and Methods}

2.1. Sample of Tea. The concentrations of boron were determined in commercially available teas in tea bags. The characteristics of analyzed teas are listed in Table 1.

2.2. Sample Tea Preparation. Two different procedures were applied in order to prepare the tea samples, including total decomposition and one single step extraction with water as an extractant. The total decomposition was carried out in a microwave system Mars Xpress (CEM, USA) based on the modified EPA 3051 method [24].

In the case of tea infusion as a water extract, $10 \mathrm{~g}$ of each sample of tea was accurately weighed into a polypropylene flask and extracted with $100 \mathrm{~mL}$ double distilled water DDW by mixing for 1 hour in $80^{\circ} \mathrm{C}$. After the extraction, the contents of the flask were filtered through a filter and then boron determination was done by the ICP-AES analytical technique, without acidification of the water tea extract.

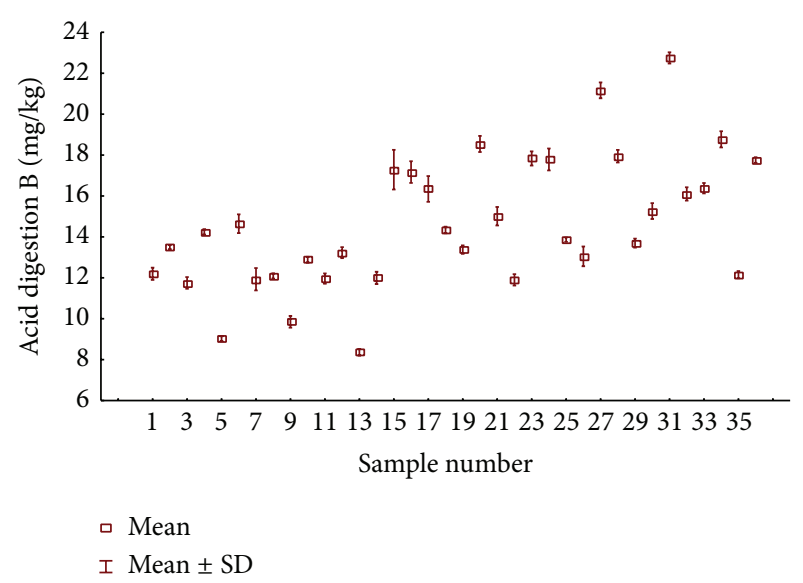

FIGURE 1: The concentration of boron $\mathrm{mg} / \mathrm{kg}$ in tea and fruit brew samples by acid extraction.

For the water extract of boron in tea, the sample $\mathrm{pH}$ was determined. The $\mathrm{pH}\left(\mathrm{H}_{2} \mathrm{O}\right)$ was determined using the Orion 5-star Plus meter (Thermo, USA) with a Single Pore pH electrode (Hamilton, USA).

2.3. Analytical Method/Apparatus. The measurements of boron in tea and fruit brew samples were carried out by the ICP-AES with radial torch equipped with argon saturation assembly (iCAP 6500 duo, Thermo, UK). The emission lines of boron used were B $208.959 \mathrm{~nm}$, B $249.678 \mathrm{~nm}$, and B $249.773 \mathrm{~nm}$. The operating condition was as follows: plasma power supply $1100 \mathrm{~kW}$, observation height $15 \mathrm{~mm}$, plasma gas flow $12 \mathrm{~L} / \mathrm{min}$, sheet gas flow $0 \mathrm{~L} / \mathrm{min}$, nebulizer gas flow $0.75 \mathrm{~L} / \mathrm{min}$, photomultiplier voltage $800 \mathrm{~V}$, sample uptake rate $1.0 \mathrm{~mL} / \mathrm{L}$, integration time $1.0 \mathrm{~s}$, and sample time delay $30 \mathrm{~s}$. The instruments were calibrated for boron before analysis. The determination of boron was performed in 3 replications, and the \%RSD did not exceed 5\%.

To check the analytical procedure of the determination of boron in water-soluble and acid soluble (total content) fractions, the determination of reference material NIST SRM 1515 (National Institute of Standards and Technology, USA) was performed. The certified value for the reference material SRM 1515 was determined by ICP-AES technique. The reference material was analyzed during six repetitions by ICP-AES technique. The mean value, standard deviation, and method recovery [\%] were calculated. The certified value for SRM 1515 (Apple Leaves) for boron is $27 \pm 2 \mathrm{mg} / \mathrm{kg}$. The determined value for acid soluble fraction (mineralization by modified EPA 3051 method) was $27.68 \pm 1.18 \mathrm{mg} / \mathrm{kg}$, with recovery $102.5 \%$, and for water-soluble fractions the obtained value was $15.19 \pm 0.494 \mathrm{mg} / \mathrm{kg}$, with recovery $56.26 \%$.

\section{Results and Discussion}

3.1. Total Concentration of Boron in Teas. The results of total content of boron in black and fruit tea are presented in Figure 1. The tea samples were distinguished as black teas (samples 1-24), black teas with fruit flavor (samples 25, 26, 
TABLE 1: Information on the tea types, ingredients, origins for the analyzed tea samples, and the result of concentration of boron in cup of tea, fruit brew samples, calculated amounts of boron in tea infusion as three cups a day $(200 \mathrm{~mL} / \mathrm{cup})$, and calculated percentage of the water soluble fraction of boron and the $\mathrm{pH}$ value for water extracts.

\begin{tabular}{|c|c|c|c|c|c|c|c|c|}
\hline Sample & Type of tea & $\begin{array}{l}\text { Composition of tea } \\
\text { and ingredients }\end{array}$ & Origin & $\begin{array}{l}\text { Tea weight } \\
\text { per bag }[\mathrm{g}]\end{array}$ & $\begin{array}{c}\text { Concentration } \\
\text { of boron in cup } \\
(200 \mathrm{~mL}) \text { of tea } \\
\text { and fruit brew } \\
{[\mathrm{mg} / 200 \mathrm{~mL}]}\end{array}$ & $\begin{array}{c}\text { Calculated } \\
\text { amounts of } \\
\text { boron in tea } \\
\text { infusion as three } \\
\text { cups a day } \\
(200 \mathrm{~mL} / \text { cup })\end{array}$ & $\begin{array}{l}\text { Calculated } \\
\text { percentage of } \\
\text { the water } \\
\text { soluble fraction } \\
\text { of boron [\%] }\end{array}$ & $\begin{array}{l}\mathrm{pH} \text { value for } \\
\text { water extracts }\end{array}$ \\
\hline 1 & Black & $100 \%$ tea leaves & $\begin{array}{l}\text { Kenya, India } \\
\text { (Assam) }\end{array}$ & 3.00 & $0.877 \pm 0.115$ & $2.630 \pm 0.345$ & 12.09 & 5.071 \\
\hline 2 & Black & $100 \%$ tea leaves & $\begin{array}{l}\text { Africa, India } \\
\text { (Assam) }\end{array}$ & 2.00 & $0.984 \pm 0.057$ & $2.951 \pm 0.172$ & 18.19 & 4.948 \\
\hline 3 & Black & $\begin{array}{c}\text { Tea leaves with } \\
\text { bergamot flavored. } \\
\text { Lemon aroma. } \\
\text { Gluten }\end{array}$ & $\begin{array}{l}\text { India, Kenya, } \\
\text { Ceylon }\end{array}$ & 1.50 & $0.829 \pm 0.041$ & $2.487 \pm 0.122$ & 23.74 & 4.811 \\
\hline 4 & Black & $100 \%$ tea leaves & $\begin{array}{c}\text { India } \\
\text { (Assam) }\end{array}$ & 2.00 & $0.955 \pm 0.020$ & $2.866 \pm 0.059$ & 16.78 & 5.288 \\
\hline 5 & Black & $100 \%$ tea leaves & $\begin{array}{l}\text { China } \\
\text { (Yunnan) }\end{array}$ & 2.00 & $0.289 \pm 0.009$ & $0.868 \pm 0.027$ & 7.983 & 4.973 \\
\hline 6 & Black & $100 \%$ tea leaves & Ceylon & 2.00 & $0.893 \pm 0.046$ & $2.680 \pm 0.138$ & 15.45 & 6.27 \\
\hline 7 & Black & $\begin{array}{l}100 \% \text { tea leaves. } \\
\text { Bergamot flavor }\end{array}$ & $\mathrm{NA}^{\mathrm{a}}$ & 2.00 & $1.144 \pm 0.050$ & $3.431 \pm 0.150$ & 24.21 & 4.653 \\
\hline 8 & Black & $\begin{array}{l}100 \% \text { tea leaves. } \\
\text { Bergamot flavor }\end{array}$ & $\begin{array}{l}\text { Ceylon } \\
\text { (region of } \\
\text { Dimbula) }\end{array}$ & 1.50 & $0.446 \pm 0.017$ & $1.338 \pm 0.051$ & 12.33 & 4.782 \\
\hline 9 & Black & $100 \%$ tea leaves & Himalayas & 1.40 & $0.621 \pm 0.028$ & $1.862 \pm 0.083$ & 22.79 & 4.567 \\
\hline 10 & Black & $100 \%$ tea leaves & Sri Lanka & 2.00 & $0.742 \pm 0.024$ & $2.226 \pm 0.073$ & 14.35 & 6.425 \\
\hline 11 & Black & $100 \%$ tea leaves & $\begin{array}{c}\text { India } \\
\text { (Assam) }\end{array}$ & 1.75 & $0.726 \pm 0.034$ & $2.178 \pm 0.101$ & 17.43 & 5.577 \\
\hline 12 & Black & $\begin{array}{l}\text { 100\% tea leaves. } \\
\text { Lemon peel }\end{array}$ & $\mathrm{NA}^{\mathrm{a}}$ & 1.70 & $0.692 \pm 0.031$ & $2.077 \pm 0.094$ & 15.47 & 4.526 \\
\hline 13 & Black & $\mathrm{NA}^{\mathrm{a}}$ & $\mathrm{NA}^{\mathrm{a}}$ & 1.75 & $0.454 \pm 0.023$ & $1.361 \pm 0.070$ & 15.61 & 4.903 \\
\hline 14 & Black & $\mathrm{NA}^{\mathrm{a}}$ & $\mathrm{NA}^{\mathrm{a}}$ & 1.50 & $0.691 \pm 0.040$ & $2.073 \pm 0.120$ & 19.39 & 5.955 \\
\hline 15 & Black & $\mathrm{NA}^{\mathrm{a}}$ & $\mathrm{NA}^{\mathrm{a}}$ & 1.50 & $1.346 \pm 0.080$ & $4.037 \pm 0.241$ & 26.56 & 4.882 \\
\hline 16 & Black & $100 \%$ tea leaves & $\begin{array}{c}\text { India } \\
\text { (Assam) }\end{array}$ & 1.30 & $1.029 \pm 0.034$ & $3.086 \pm 0.101$ & 23.24 & 6.887 \\
\hline 17 & Black & $100 \%$ tea leaves & Sri Lanka & 1.75 & $0.921 \pm 0.040$ & $2.763 \pm 0.121$ & 16.32 & 4.737 \\
\hline 18 & Black & $\begin{array}{l}100 \% \text { tea Leaves. } \\
\text { Bergamot flavor }\end{array}$ & $\begin{array}{l}\text { Indonesia, } \\
\text { Kenya, Sri } \\
\text { Lanka }\end{array}$ & 1.40 & $1.091 \pm 0.051$ & $3.274 \pm 0.153$ & 21.80 & 4.62 \\
\hline 19 & Black & $\mathrm{NA}^{\mathrm{a}}$ & $\mathrm{NA}^{\mathrm{a}}$ & 1.40 & $0.757 \pm 0.028$ & $2.270 \pm 0.085$ & 20.30 & 4.866 \\
\hline 20 & Black & $\mathrm{NA}^{\mathrm{a}}$ & $\mathrm{NA}^{\mathrm{a}}$ & 2.00 & $1.171 \pm 0.058$ & $3.513 \pm 0.174$ & 22.73 & 4.505 \\
\hline 21 & Black & $\mathrm{NA}^{\mathrm{a}}$ & $\mathrm{NA}^{\mathrm{a}}$ & 1.50 & $1.454 \pm 0.064$ & $4.363 \pm 0.192$ & 24.53 & 4.582 \\
\hline 22 & Black & $\mathrm{NA}^{\mathrm{a}}$ & $\mathrm{NA}^{\mathrm{a}}$ & 1.50 & $0.953 \pm 0.375$ & $2.859 \pm 1.126$ & 26.95 & 5.829 \\
\hline 23 & Black & $\mathrm{NA}^{\mathrm{a}}$ & $\mathrm{NA}^{\mathrm{a}}$ & 1.40 & $1.208 \pm 0.054$ & $3.624 \pm 0.163$ & 22.73 & 5.266 \\
\hline 24 & Black & $\mathrm{NA}^{\mathrm{a}}$ & $\mathrm{NA}^{\mathrm{a}}$ & 1.40 & $1.145 \pm 0.057$ & $3.436 \pm 0.171$ & 23.26 & 5.047 \\
\hline 25 & Fruit & $\begin{array}{l}\text { Tea leaves with } \\
\text { strawberry flavor }\end{array}$ & Sri Lanka & 1.50 & $0.725 \pm 0.030$ & $2.176 \pm 0.090$ & 17.41 & 4.765 \\
\hline 26 & Fruit & $\begin{array}{l}\text { Tea leaves with } \\
\text { strawberry flavor }\end{array}$ & $\mathrm{NA}^{\mathrm{a}}$ & 1.40 & $0.887 \pm 0.048$ & $2.660 \pm 0.144$ & 24.65 & 4.578 \\
\hline
\end{tabular}


TABle 1: Continued.

\begin{tabular}{|c|c|c|c|c|c|c|c|c|}
\hline Sample & Type of tea & $\begin{array}{l}\text { Composition of tea } \\
\text { and ingredients }\end{array}$ & Origin & $\begin{array}{l}\text { Tea weight } \\
\text { per bag }[\mathrm{g}]\end{array}$ & $\begin{array}{l}\text { Concentration } \\
\text { of boron in cup } \\
(200 \mathrm{~mL}) \text { of tea } \\
\text { and fruit brew } \\
{[\mathrm{mg} / 200 \mathrm{~mL}]}\end{array}$ & $\begin{array}{c}\text { Calculated } \\
\text { amounts of } \\
\text { boron in tea } \\
\text { infusion as three } \\
\text { cups a day } \\
(200 \mathrm{~mL} / \text { cup })\end{array}$ & $\begin{array}{l}\text { Calculated } \\
\text { percentage of } \\
\text { the water } \\
\text { soluble fraction } \\
\text { of boron [\%] }\end{array}$ & $\begin{array}{l}\mathrm{pH} \text { value for } \\
\text { water extracts }\end{array}$ \\
\hline 27 & Fruit brew & $\begin{array}{l}\text { Hibiscus. } \\
\text { Rosehip. Apple. } \\
\text { Orange peel. } \\
\text { Raspberry. } \\
\text { Elderberry fruit }\end{array}$ & $\mathrm{NA}^{\mathrm{a}}$ & 2.50 & $7.241 \pm 0.368$ & $21.72 \pm 1.105$ & 68.56 & 2.702 \\
\hline 28 & Fruit brew & $\begin{array}{c}\text { Hibiscus. } \\
\text { Chokeberry. } \\
\text { Apple. } \\
\text { Blackberry leaf. } \\
\text { Rosehip. Flavors. } \\
\text { Lemon peel. } \\
\text { Orange Peel. } \\
\text { Black Currant. } \\
\text { Strawberry fruit } \\
0.1 \%\end{array}$ & $\mathrm{NA}^{\mathrm{a}}$ & 2.00 & $3.031 \pm 0.101$ & $9.094 \pm 0.302$ & 42.50 & 2.641 \\
\hline 29 & Fruit brew & $\begin{array}{c}\text { Hibiscus Flower. } \\
\text { Wild rose } 20 \% \text {. } \\
\text { Black currant } 11 \% \text {. } \\
\text { Aronia } 10 \% \text {. Apple } \\
\text { 9.3\%. Orange peel } \\
2 \%\end{array}$ & $\mathrm{NA}^{\mathrm{a}}$ & 2.30 & $2.793 \pm 0.081$ & $8.379 \pm 0.243$ & 44.61 & 2.741 \\
\hline 30 & Fruit & $\begin{array}{l}\text { Tea leaves. } \\
\text { Ginger }\end{array}$ & Ceylon & 1.50 & $1.193 \pm 0.062$ & $3.580 \pm 0.185$ & 26.29 & 4.533 \\
\hline 31 & Fruit brew & $\begin{array}{c}\text { Hibiscus. } \\
\text { Apple. Blackberry } \\
\text { leaf. } \\
\text { Flavors. } \\
\text { Rosehip fruit } \\
\text { cranberries } 1 \% \\
\text { citric acid. } \\
\text { Acidity } \\
\text { regulator-fruit } \\
\text { raspberry } 0.3 \%\end{array}$ & $\mathrm{NA}^{\mathrm{a}}$ & 2.00 & $4.940 \pm 0.226$ & $14.82 \pm 0.679$ & 54.24 & 2.560 \\
\hline 32 & Fruit brew & $\begin{array}{c}\text { Wild rose 55\%. } \\
\text { Hibiscus flower } \\
30 \% . \\
\text { Raspberry flavor. } \\
\text { Raspberry fruit 3\%. } \\
\text { Citric acid. Acidity } \\
\text { regulator }\end{array}$ & $\mathrm{NA}^{\mathrm{a}}$ & 2.00 & $3.258 \pm 0.107$ & $9.775 \pm 0.321$ & 50.85 & 2.656 \\
\hline 33 & Fruit brew & $\begin{array}{l}\text { Rosehip. Hibiscus } \\
\text { flower. } \\
\text { Cherry flavor. } \\
\text { Granulated yogurt } \\
1 \%\end{array}$ & $\mathrm{NA}^{\mathrm{a}}$ & 3.00 & $5.828 \pm 0.327$ & $17.48 \pm 0.980$ & 59.37 & 2.958 \\
\hline
\end{tabular}


TABle 1: Continued.

\begin{tabular}{|c|c|c|c|c|c|c|c|c|}
\hline Sample & Type of tea & $\begin{array}{l}\text { Composition of tea } \\
\text { and ingredients }\end{array}$ & Origin & $\begin{array}{l}\text { Tea weight } \\
\text { per bag }[\mathrm{g}]\end{array}$ & $\begin{array}{l}\text { Concentration } \\
\text { of boron in cup } \\
(200 \mathrm{~mL}) \text { of tea } \\
\text { and fruit brew } \\
{[\mathrm{mg} / 200 \mathrm{~mL}]}\end{array}$ & $\begin{array}{c}\text { Calculated } \\
\text { amounts of } \\
\text { boron in tea } \\
\text { infusion as three } \\
\text { cups a day } \\
(200 \mathrm{~mL} / \text { cup })\end{array}$ & $\begin{array}{l}\text { Calculated } \\
\text { percentage of } \\
\text { the water } \\
\text { soluble fraction } \\
\text { of boron [\%] }\end{array}$ & $\begin{array}{l}\mathrm{pH} \text { value for } \\
\text { water extracts }\end{array}$ \\
\hline 34 & Fruit brew & $\begin{array}{c}\text { Hibiscus flower. } \\
\text { Apple, } \\
\text { blackcurrant } 7 \% . \\
\text { Raspberry 6\%. } \\
\text { Licorice } 4 \% . \\
\text { Blackberry 4\%. } \\
\text { Blueberry 4\%. } \\
\text { Dried juice of 2\%. } \\
\text { Malic acid. } \\
\text { Acidity regulator }\end{array}$ & $\mathrm{NA}^{\mathrm{a}}$ & 2.00 & $3.799 \pm 0.102$ & $11.40 \pm 0.306$ & 51.00 & 2.644 \\
\hline 35 & Fruit brew & $\begin{array}{c}\text { Raspberry } 40 \% . \\
\text { Chokeberry. } \\
\text { Elderberry. } \\
\text { Apple. Flavoring. } \\
\text { Citric acid }\end{array}$ & $\mathrm{NA}^{\mathrm{a}}$ & 2.00 & $2.524 \pm 0.106$ & $7.573 \pm 0.319$ & 52.20 & 2.809 \\
\hline 36 & Fruit brew & $\begin{array}{c}\text { Wild rose } 56 \% \text {, } \\
\text { hibiscus. } \\
\text { Raspberry flavor. } \\
\text { Raspberry (1\% } \\
\text { fruit. } \\
\text { Maltodextrin-from } \\
\text { starch) }\end{array}$ & $\mathrm{NA}^{\mathrm{a}}$ & 2.00 & $4.052 \pm 0.150$ & $12.16 \pm 0.450$ & 57.07 & 2.804 \\
\hline
\end{tabular}

and 30), and fruit teas as typical fruit brews (samples 27-29 and 31-36). The highest total content of boron in black tea was $18.4 \mathrm{mg} / \mathrm{kg}$ (sample 20), and the lowest was $8.31 \mathrm{mg} / \mathrm{kg}$ (sample 13). For black tea with fruit flavor, the boron concentration amounted to $12.9-15.1 \mathrm{mg} / \mathrm{kg}$. In fruit brew samples, boron content was determined at a higher level (from 12.1 to $22.8 \mathrm{mg} / \mathrm{kg}$ ). However, the average total concentrations of boron were as follows: fruit brew 17.4> black tea with fruit flavors $13.9>$ black tea $13.5 \mathrm{mg} / \mathrm{kg}$. It should also be noted that, in the group classified as fruit tea, only samples 25,26 , and 30 contained tea leaves; the remaining samples consisted of a mix of dried fruit. Thus, the total concentrations of boron indicated were similar to those obtained for typical black teas. The boron concentrations determined by Krejčová and Černohorský [16] in black tea samples were on the level of mean values determined by us, while the boron concentrations in fruit brews were also higher in comparison with black teas. Özcan et al. [26] studied the mineral content of herbs and teas, determining boron in black tea samples at the range of $6.8-24.6 \mathrm{mg} / \mathrm{kg}$. Malik et al. [27] determined total content of boron in black tea at the range of 14.2 to $21.1 \mathrm{mg} / \mathrm{kg}$, while in the rooibos (Aspalathus linearis) plants (green and red species) the element content was determined at range from $13.0-20.3 \mathrm{mg} / \mathrm{kg}$, which is in accordance with the concentrations obtained for fruit brew samples.

In turn, in Hibiscus sabdariffa L. (Malvaceae), commonly known as Roselle, which is one of the most economically important herbal tea plant species [28] determined the content of boron at the range of 19.18 to $27.44 \mathrm{mg} / \mathrm{kg}$. Our results for the total content of boron in fruit teas which contain hibiscus are in accordance with those of [28]. It is worthy to say that in some herbal teas the concentration of boron is much higher than in typical black or fruit teas. For example, the determined content of boron in sage (Salvia fruticosa L.) was $46.7 \mathrm{mg} / \mathrm{kg}$, in coriander (Coriandrum sativum L.) it was 41.8 by Özcan et al. [26], for nettle (Urtica dioica) it was $61.00 \mathrm{mg} / \mathrm{kg}$ by Pytlakowska et al. [29], and for Ginkgo biloba L. (Ginkgoaceae) it was $167.8 \mathrm{mg} / \mathrm{kg}$ by Stefanovits-Bányai et al. [30]. Summing up the content of boron varied between 8.31 and $22.8 \mathrm{mg} / \mathrm{kg}$ in the analyzed tea samples. According to the literature, most of the investigated foodstuffs contained less than $1 \mathrm{mg} / \mathrm{kg}$ of B; for example, $0.074 \mathrm{mg} / \mathrm{kg}$ was found in chicken, $0.82 \mathrm{mg} / \mathrm{kg}$ in dried shrimp, and $0.55 \mathrm{mg} / \mathrm{kg}$ in rice [8].

3.2. Water Soluble Fraction of Boron in Tea Samples. Boron was determined in water-soluble fraction in the same type of tea samples as for the total content determination (Figure 2). The highest concentration of boron in water-soluble fraction in black teas was determined in sample $15(4.49 \mathrm{mg} / \mathrm{kg})$ and the lowest in sample $5(0.72 \mathrm{mg} / \mathrm{kg})$. It was observed that the concentrations of boron in water-soluble fraction of fruit teas are several fold higher in comparison with the boron concentrations found in black teas. The highest concentration of boron in water soluble fraction in fruit brew samples was $14.48 \mathrm{mg} / \mathrm{kg}$ and it was on the level of total 


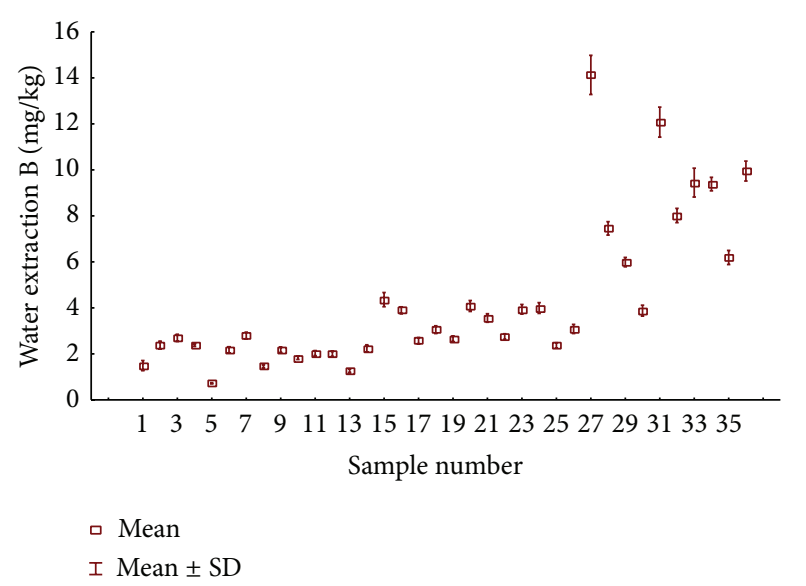

FIGURE 2: The concentration of boron $\mathrm{mg} / \mathrm{kg}$ in tea and fruit brew samples by water extraction.

boron concentrations determined in black teas. Krejčová and Černohorský [16] determined boron in water-soluble extracts within the range from 3.21 to $9.25 \mathrm{mg} / \mathrm{kg}$ in black teas and from 2.71 to $27.7 \mathrm{mg} / \mathrm{kg}$ in fruit teas.

It should be also noted that, in the group of teas classified as fruit teas, only samples 25,26 , and 30 contained tea leaves, while the remaining samples contained a mix of dried fruit (Table 1). That is why the boron concentrations, both total and those determined in water-soluble fraction, are at a similar level as the concentrations in black teas. Higher concentrations of boron in water-soluble fraction of fruit tea samples may be linked to the fact that these samples consisted of dried fruit, which contain higher concentrations of boron than tea leaves.

Extraction efficiency was calculated as a ratio of boron concentration in the water-soluble fraction to the element concentration in tea samples obtained after the complete decomposition in the microwave system (Table 1). The extraction level of boron for black teas ranged between $8 \%$ and $27 \%$, and for fruit tea it was from $17 \%$ to $69 \%$. In addition, the values lower than $25 \%$ were found for black teas with fruit flavours (samples 25, 26, and 30). It should be noted that a very high level of boron extraction was obtained from tea samples containing a mix of dried fruit, using the least aggressive extractant that is water.

According to the extraction efficiencies boron has been classified as the element moderately extractable within the range of 20 to $55 \%$, which is in accordance with results obtained by us [12]. Also, the high levels of boron extraction obtained in the samples of dried fruit teas may be the evidence of another mechanism of binding boron in fruit in comparison with black tea leaves, especially considering the fact that fruits contain numerous polyphenols, which consist, among others, of mono sugars and other compounds containing cis-hydroxyl groups which can form complexes with boron (e.g., as boron-diol complexes with mannitol or sorbitol) $[1,4,5,7]$.

Besides, the obtained results of $\mathrm{pH}$ value of water-soluble fraction of tea samples (Table 1) indicate that a lower $\mathrm{pH}$ in the case of fruit brew favors higher concentrations of boron in the water fraction, and it can be connected with greater degree of leaching of boron to the infusion. In the case of black teas it was observed that at higher $\mathrm{pH}$ values determined boron concentration was much lower than those marked in the fruit teas.

3.3. Concentration of Boron in Cup of Tea. According to current studies, regular consumption of tea can be significantly associated with the daily dietary uptake of certain elements [28]. Taking into account that the quantitative estimate of boron is of particular importance in order to assure its nutritional integrity and, in consequence, the human health. That is why the potential concentration of boron in a cup of tea (in our case $200 \mathrm{~mL}$ ) was calculated, based on the results determined for water-soluble fraction of tea samples (Table 1).

The results indicate that the boron concentration varies between $0.29-1.45 \mathrm{mg} /$ per a cup of black tea, $0.73-1.19 \mathrm{mg} / \mathrm{per}$ a cup of black tea with fruit flavours, and 2.52-7.24 mg/per a cup of fruit brew. According to the literature, the main source of dietary B is beverages (31\%); the amount contained in hibiscus (up to $5.579 \mathrm{mg} / \mathrm{L}$ ) makes it possibly one of the top B contributors for humans [28]. Also in our findings the highest concentration of boron was found in tea containing hibiscus (sample 27). One should remember that typical fruit teas are produced from dried fruit-dried raspberries, cherries, blackberries, and cranberries. These are often mixed with hibiscus flower (which can be found in almost every fruit tea), as well as with fruit or wild rose petals and with the addition of herbs. For the above reason, such beverage is not real tea, but rather an infusion, as it does not contain tea leaves (Camellia sinensis). Moreover, the boron concentrations determined by Özcan et al. [26], in the infusion of teas, were much lower and amounted to $0.035 \mathrm{mg} \mathrm{B} / 100 \mathrm{~mL}$ for the infusion of black tea and $0.214 \mathrm{mg} \mathrm{B/100} \mathrm{mL}$ for Matricaria chamomilla. Özcan et al. [26] marked by an order of magnitude lower boron concentration in the infusion of black tea compared to the herbs. This finding is in accordance with our results, where determined concentrations in black tea were also much lower in comparison with dose of fruit brew sample.

It should be noted that the content of metals, including boron, in teas and infusions may depend on physiological properties or structures of ingredients of teas, levels of phytochelatin phenolic, other mineral-binding components, and the $\mathrm{pH}$ of the water used in tea preparation and on the solubility of metals and other mineral elements in hot water $[10,12,31]$.

The obtained results of concentration of boron in cup of tea were compared with upper limit for boron intake which is given in Table 2 [25].

The presented ranges of concentrations for the daily boron intake vary considerably depending on the research centre which conducted the determinations. Nevertheless, the determined concentrations of boron in a cup of tea are relatively high, especially for fruit teas.

In order to estimate the potential health risk associated with the consumption of boron, the total amount of boron tea 
TABLE 2: Reference data of daily intake of boron for human acquired from literature [25].

\begin{tabular}{|c|c|c|}
\hline Name of organizations & $\begin{array}{l}\text { Acceptable/safe levels of daily intake of } \\
\text { boron by human [mg/day] }\end{array}$ & Type of sample \\
\hline $\begin{array}{l}\text { Scientific Panel on Dietetic Products, Nutrition and } \\
\text { Allergies }\end{array}$ & $3-10$ & $\begin{array}{l}\text { Food, dietary } \\
\text { supplements, } \\
\text { and drinking } \\
\text { water }\end{array}$ \\
\hline $\begin{array}{l}\text { NCEA (National Center for Environmental Assessment } \\
\text { of the Environmental Protection Agency (EPA) }\end{array}$ & 14 & Drinking water \\
\hline EFSA (European Food Safety Authority) & $\begin{array}{c}10 \text { (adults) } \\
3 \text { (1-3 yrs); } 4 \text { (4-6 yrs); } 5 \text { (7-10 yrs), } 7 \\
\text { (11-14 yrs), } 9 \text { (15-17 yrs) }\end{array}$ & Drinking water \\
\hline EVGM (Expert Group on Vitamins and Minerals) & 10 & $\begin{array}{l}\text { Food, dietary } \\
\text { supplements, } \\
\text { and drinking } \\
\quad \text { water }\end{array}$ \\
\hline FNB (US Food and Nutrition Board) & 20 & $\begin{array}{l}\text { Food, dietary } \\
\text { supplements, } \\
\text { and drinking } \\
\text { water }\end{array}$ \\
\hline WHO (World Health Organization) & $1-13$ & $\begin{array}{l}\text { Food, dietary } \\
\text { supplements, } \\
\text { and drinking } \\
\quad \text { water }\end{array}$ \\
\hline $\begin{array}{l}\text { Tolerable intake (TI) by WHO (World Health } \\
\text { Organization) }\end{array}$ & $28 \mathrm{mg} /$ day for a $70 \mathrm{~kg}$ adult & $\begin{array}{l}\text { Food, dietary } \\
\text { supplements, } \\
\text { and drinking } \\
\text { water }\end{array}$ \\
\hline
\end{tabular}

infusions was calculated for the daily intake. The calculated amounts are based on the concentrations of boron in tea infusion as a cup of tea and the assumption that the average consumption of tea for a single person is three cups a day (each with $200 \mathrm{~mL}$ per cup) with one single tea bag and are presented in Table 1.

Taking into account the fact that we drink more than one cup of tea on average and assuming the determined boron concentrations in a cup of tea, only drinking tea itself covers and for certain tea samples (fruit brew) even exceeds safety regulations of the daily intake of boron by humans. Murray and Schlekat [32] analysed the defined by the other researchers tolerable daily boron intake recommendations amounting from 10 to 24 and 12 to $28 \mathrm{mg} \mathrm{B/day} \mathrm{for} 60 \mathrm{~kg}$ women and $70 \mathrm{~kg}$ men, respectively. The safe boron intake level for human was estimated by seven different research centers, which were based on the same, single study in rats. That is why the ranges of boron concentration in the daily human diet assumed as not harmful should be treated as arbitrary and not reflecting the actual boron concentrations consumed.

\section{Conclusions}

Based upon the obtained results of this study, the following conclusions can be made.

Fruit brew samples (both acid and water soluble fraction) have boron concentrations greater than the concentration obtained in typical black teas. As a result, teas, especially fruit, were found to be significant sources of boron. The average concentration of boron in a cup of tea was about 4.5-fold higher in fruit teas than in black teas. Fruit teas containing hibiscus were marked by the highest concentrations of boron in comparison with the other investigated teas. Regular daily intake of tea (3 cups), especially ones with dried fruit, covers the daily demand for boron in humans.

It was found that, with respect to acceptable daily intake boron (three cups/day) in daily dietary standards, the infusion of black tea samples analyzed in the present study was found to be safe for human consumption. On the other hand some of the fruit brews exceed acceptable regulations of the daily intake of total boron by humans. However it may not produce any health risks for human consumption, if other sources of metal contaminated food are not taken at the same time.

That is why it is important to determine the concentration of boron in food, beverages, dietary supplements, and care products to avoid overconsumption and accumulation of boron over a long period of use.

\section{Conflict of Interests}

The authors declared that there is no conflict of interests.

\section{References}

[1] M. Herera-Rodrigez, A. González-Fontes, J. Rexach et al., "Role of boron in vascular plants and respononse mechanisms to boron stresses," Plant Stress, vol. 4, no. 2, pp. 115-122, 2010. 
[2] N. Hilal, G. J. Kim, and C. Somerfield, "Boron removal from saline water: a comprehensive review," Desalination, vol. 273, no. 1, pp. 23-35, 2011.

[3] M. Burguera, J. L. Burguera, C. Rondón, and P. Carrero, "Determination of boron in blood, urine and bone by electrothermal atomic absorption spectrometry using zirconium and citric acid as modifiers," Spectrochimica Acta B: Atomic Spectroscopy, vol. 56, no. 10, pp. 1845-1857, 2001.

[4] P. Carrero, A. Malavé, E. Rojas et al., "On-line generation and hydrolysis of methyl borate for the spectrophotometric determination of boron in soil and plants with azomethine- $\mathrm{H}$," Talanta, vol. 68, no. 2, pp. 374-381, 2005.

[5] F. S. Kot, "Boron sources, speciation and its potential impact on health," Reviews in Environmental Science and Biotechnology, vol. 8, no. 1, pp. 3-28, 2009.

[6] M. Resano, J. Briceño, M. Aramendía, and M. A. Belarra, "Solid sampling-graphite furnace atomic absorption spectrometry for the direct determination of boron in plant tissues," Analytica Chimica Acta, vol. 582, no. 2, pp. 214-222, 2007.

[7] L. Bolaños, K. Lukaszewski, I. Bonilla, and D. Blevins, "Why boron?" Plant Physiology and Biochemistry, vol. 42, no. 11, pp. 907-912, 2004.

[8] L. Zaijun, C. Zhengwei, and T. Jian, "The determination of boron in food and seed by spectrophotometry using a new reagent 3,4-dihydroxyazomethine-H," Food Chemistry, vol. 94, no. 2, pp. 310-314, 2006.

[9] H. W. Wiley, Influence of Food Preservatives and Artificial Colors on Digestion and Health. I. Boric Acid and Borax, vol. 84, US Department of Agriculture Bulletin, 1904.

[10] M. Dambiec, L. Polechońska, and A. Klink, "Levels of essential and non-essential elements in black teas commercialized in Poland and their transfer to tea infusion," Journal of Food Composition and Analysis, vol. 31, no. 1, pp. 62-66, 2013.

[11] R. Horanni and U. H. Engelhardt, "Determination of amino acids in white, green, black, oolong, pu-erh teas and tea products," Journal of Food Composition and Analysis, vol. 31, no. 1, pp. 94-100, 2013.

[12] A. Szymczycha-Madeja, M. Welna, and P. Pohl, "Elemental analysis of teas and their infusions by spectrometric methods," Trends in Analytical Chemistry, vol. 35, pp. 165-181, 2012.

[13] A. Koblar, G. Tavčar, and M. Ponikvar-Svet, "Fluoride in teas of different types and forms and the exposure of humans to fluoride with tea and diet," Food Chemistry, vol. 130, no. 2, pp. 286-290, 2012.

[14] M. Frankowski, "Aluminium and its complexes in teas and fruity brew samples, speciation and ions determination by ion chromatography and high-performance liquid chromatography-fluorescence analytical methods," Food Analytical Methods, vol. 7, no. 5, pp. 1109-1117, 2014.

[15] M. Rajput, V. K. Jain, D. P. Jain, M. Aggarwal, and R. K. Khandal, "Quantitative determination of boron content in tamsulosin hydrochloride using inductively coupled plasma optical emission spectroscopy," International Journal of Pharmacy and Pharmaceutical Sciences, vol. 2, no. 4, pp. 182-185, 2010.

[16] A. Krejčová and T. Černohorský, "The determination of boron in tea and coffee by ICP-AES method," Food Chemistry, vol. 82, pp. 303-308, 2003.

[17] A. Şimşek, D. Korkmaz, Y. S. Velioǧlu, and O. Y. Ataman, "Determination of boron in hazelnut (Corylus avellana L.) varieties by inductively coupled plasma optical emission spectrometry and spectrophotometry," Food Chemistry, vol. 83, no. 2, pp. 293-296, 2003.
[18] Y. Yücel and P. Sultanoğlu, "Characterization of Hatay honeys according to their multi-element analysis using ICP-OES combined with chemometrics," Food Chemistry, vol. 140, no. 1-2, pp. 231-237, 2013.

[19] K. Phan-Thien, G. C. Wright, and N. A. Lee, "Inductively coupled plasma-mass spectrometry (ICP-MS) and -optical emission spectroscopy (ICP-OES) for determination of essential minerals in closed acid digestates of peanuts (Arachis hypogaeaL.)," Food Chemistry, vol. 134, no. 1, pp. 453-460, 2012.

[20] J. Naozuka, E. Carvalho Vieira, A. N. Nascimento, and P. V. Oliveira, "Elemental analysis of nuts and seeds by axially viewed ICP OES," Food Chemistry, vol. 124, no. 4, pp. 1667-1672, 2011.

[21] G. A. Chope and L. A. Terry, "Use of canonical variate analysis to differentiate onion cultivars by mineral content as measured by ICP-AES," Food Chemistry, vol. 115, no. 3, pp. 1108-1113, 2009.

[22] C. Rubio, J. R. D. Lucas, A. J. Gutiérrez et al., "Evaluation of metal concentrations in mentha herbal teas (Mentha piperita, Mentha pulegium and Mentha species) by inductively coupled plasma spectrometry," Journal of Pharmaceutical and Biomedical Analysis, vol. 71, pp. 11-17, 2012.

[23] A. S. Szabo and D. W. Golightly, "Determination of boron in liquid nutritional foods by ICP-AES," Journal of Food Composition and Analysis, vol. 8, no. 3, pp. 220-231, 1995.

[24] M. Frankowski, A. Zioła-Frankowska, and J. Siepak, "From soil to leaves: aluminum fractionation by single step extraction procedures in polluted and protected areas," Journal of Environmental Management, vol. 127, pp. 1-9, 2013.

[25] S. Meacham, S. Karakas, A. Wallace, and F. Altun, "Boron in human health: evidence for dietary recommendations and public policies," The Open Mineral processing Journal, vol. 3, pp. 36-53, 2010.

[26] M. Özcan, A. Ünver, T. Uçar, and D. Arslan, "Mineral content of some herbs and herbal teas by infusion and decoction," Food Chemistry, vol. 106, no. 3, pp. 1120-1127, 2008.

[27] J. Malik, J. Szakova, O. Drabek, J. Balik, and L. Kokoska, "Determination of certain micro and macroelements in plant stimulants and their infusions," Food Chemistry, vol. 111, no. 2, pp. 520-525, 2008.

[28] J. Malik, A. Frankova, O. Drabek, J. Szakova, C. Ash, and L. Kokoska, "Aluminium and other elements in selected herbal tea plant species and their infusions," Food Chemistry, vol. 139, no. 1-4, pp. 728-734, 2013.

[29] K. Pytlakowska, A. Kita, P. Janoska, M. Połowniak, and V. Kozik, "Multi-element analysis of mineral and trace elements in medicinal herbs and their infusions," Food Chemistry, vol. 135, no. 2, pp. 494-501, 2012.

[30] É. Stefanovits-Bányai, K. Szentmihályi, A. Hegedus et al., "Metal ion and antioxidant alterations in leaves between different sexes of Ginkgo biloba L.", Life Sciences, vol. 78, no. 10, pp. 1049-1056, 2006.

[31] M. Welna, A. Szymczycha-Madeja, and P. Pohl, "A comparison of samples preparation strategies in the multi-elemental analysis of tea by spectrometric methods," Food Research International, vol. 53, no. 2, pp. 922-930, 2013.

[32] F. J. Murray and C. E. Schlekat, "Comparison of risk assessments of boron: alternate approaches to chemical-specific adjustment factors," Human and Ecological Risk Assessment, vol. 10, no. 1, pp. 57-68, 2004. 


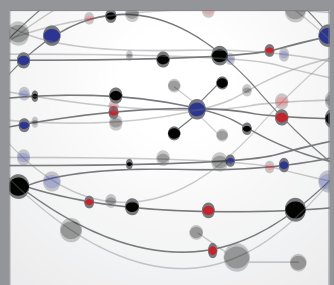

The Scientific World Journal
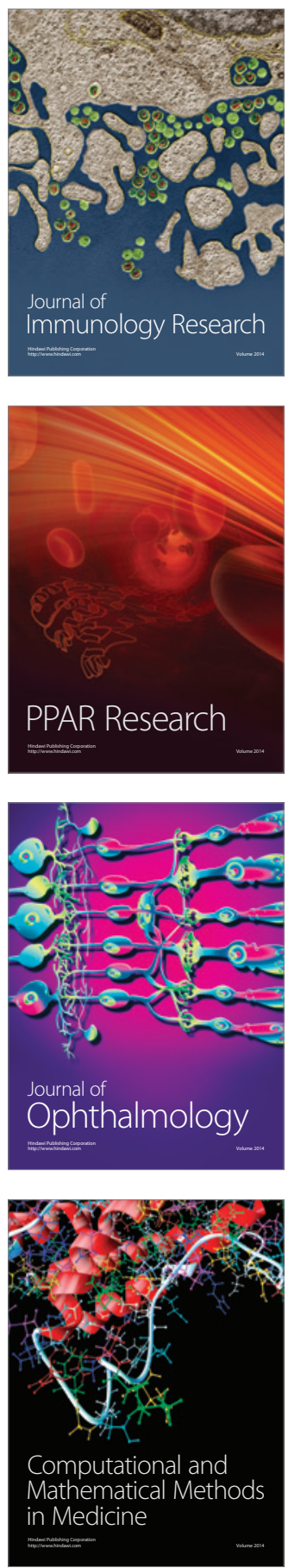

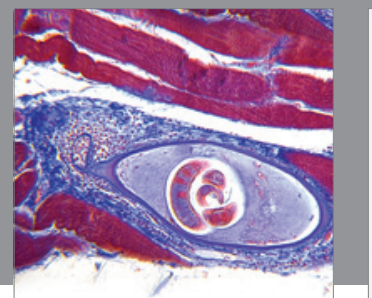

Gastroenterology

Research and Practice
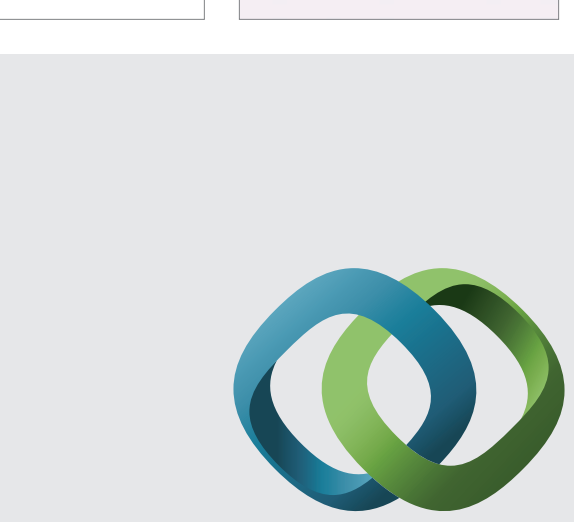

\section{Hindawi}

Submit your manuscripts at

http://www.hindawi.com
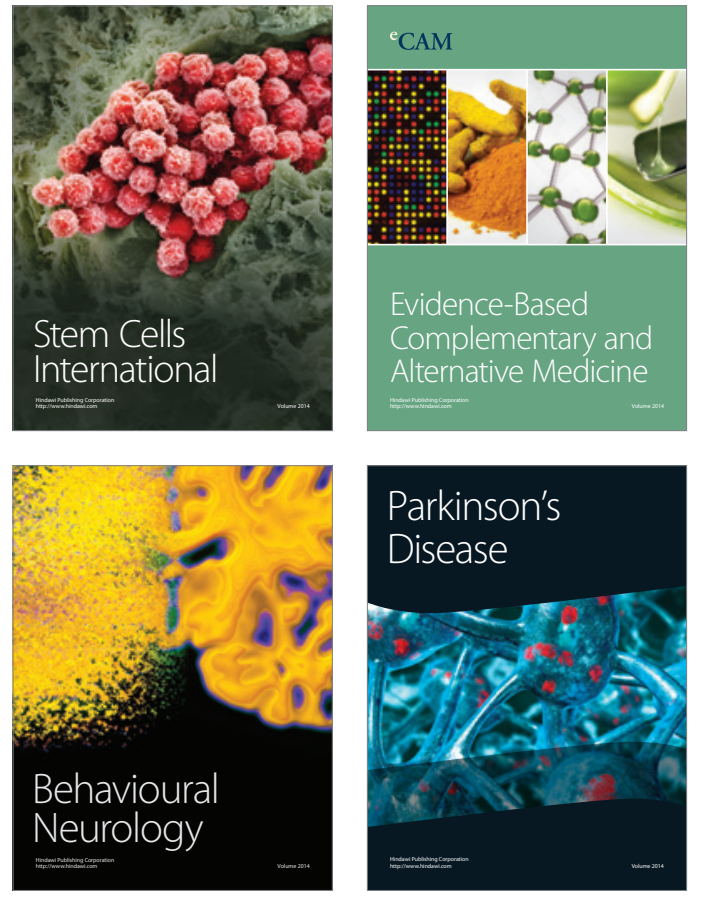
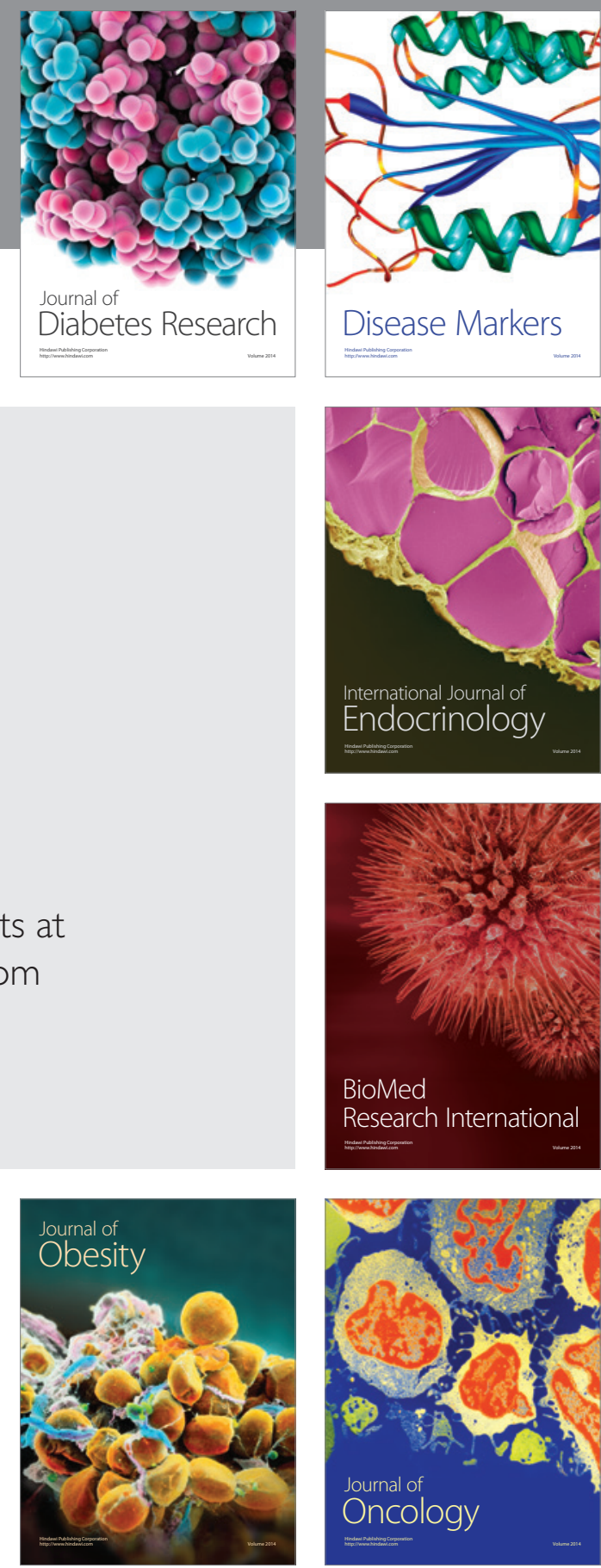

Disease Markers
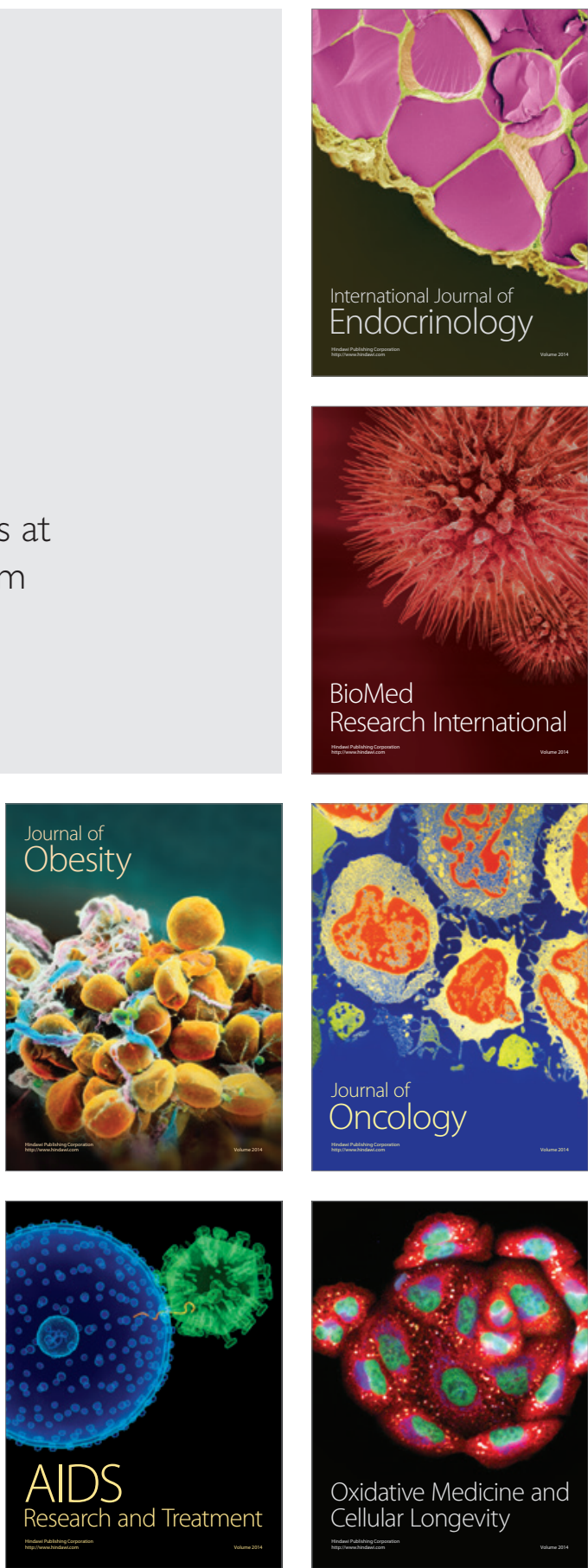